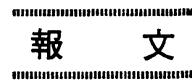 \\ 重油燃焼ボイラの燃焼ガスによる腐食試験と 空気予熱器付着物について
}

\author{
大塚 唯 男* 一田

\section{Studies on Corrosion by Combustion Gas and Air-preheater Deposits in Oil Firing Boilers}

修*

Tadao Ohtsuka and Osamu Shimoda

Air preheater corrosion in oil firing boilers has been the subject of many research works, but almost all workers have not made any mentions on the relations between corrosion and deposits. We have examined the corrosion phenomena by deposit analysis with chemical and physical method, i. e. X-ray difraction or infrared spectroanalysis. Results are summarized as follows.
1) With the decrease in the surface temperature, corrosion and acid deposition on metal surface are highly increased, and this seems to be different from D. H. Kear's result, who observed a peak in the corrosion rate.

2) A correlation exists between the free acid contents (or $\mathrm{Fe}^{2+} / \mathrm{Fe}^{3+}$ ) and combustible residue contents in the deposits.

\section{1. 緒}

近年の電力需要の著しい伸びに応じて, 発電設備も年 々飛躍的な増設が行なわれているが, 特に火主水良の線 にそった火力発電設備の新設と, その大容量化には目ざ ましいものがある。これに対応する燃料としては, わが 国の石琶标情から考えて, 今後石炭に加うるに重油の使 用増加が予想されている。しかしながら重油燃焼ボイラ においては, 重油中のバナジウム, 硫黄などによりボイ ラ高温部あるいは低温部の燃焼ガス側に污損がみられる ようである。輸入原油の大半が硫黄分の多い中東原油で あるという実情から, 硫黄分による低温部の污損が当面 の問題とみられている。すなわち, この重油中の硫黄分 は燃焼により, 亜硫酸ガスとなるが, 同時に生成した微 量の硫酸がボイラの低温蔀に凝縮し，そこを腐食させる ためである。特に空気予熱器は硫酸を含む燃焼ガスがは じめてふれる低温表面であるため, 最も腐食をうけやす い部分となる。このような燃焼ガスによる腐食に闒する 研究 ${ }^{1)}$ は, 重油の使用が世界的に高まっているので, 各 国で行なわれ，また低温伝熱面の腐食を対象とした研 究2)も多い。しかし実情を調査してみると, この空父子 熱器には, 腐食の外に同時に付着物の推積が見うけられ る。空父予熱器における付着物については, ほとんど検 討されていないようであるが，この部分における腐食を 検討するにあたって, 空気子熱器付着物の堆積は切り離 せない要因であると考えられる。よって腐食プローブ (腐食試験片)による腐食試験, および空気予熱器付着物

* 財団法人電力中央研究所技術研究所 (東京都北多摩郡狛江町岩戸)
の分析などより，この低温部表面における付着物の生成 と腐食についての検討を行なった。

\section{2. 試 験 方 法}

燃焼ガスによる腐食試験は，軟鋼試験片を取付けた腐 食プローブを用い，空匃予熱器の付着物はユングストロ 一ム型空気子熱器および鋼管型空父子熱器より採取した ものについて分析を行なった。試験が行なわれたボイラ の概要は表 1 に示す。

表 1 ボイラの概要

\begin{tabular}{|c|c|c|c|}
\hline \multirow{2}{*}{ ボ } & \multirow{2}{*}{ ラ } & \multicolumn{2}{|c|}{ 東京電力KK鶴見発電所 } \\
\hline & & No. $4 \mathrm{~B}$ & No. $11 \mathrm{~B}$ \\
\hline 型 & 式 & $\begin{array}{l}\text { B \& W (旦) } \\
\text { 单胴幅射型 }\end{array}$ & 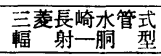 \\
\hline 力 & MW & 66 & - \\
\hline $\begin{array}{l}\text { 蒸 } 大^{\text {発 }}{ }^{\text {量 }} \text { 繶) } \\
\end{array}$ & $\mathbf{T} / \mathbf{H}$ & 280 & 160 \\
\hline 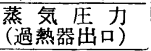 & $\mathrm{kg} / \mathrm{cm}^{2}$ & 91 & 45 \\
\hline 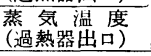 & ${ }^{\circ} \mathrm{C}$ & 513 & 430 \\
\hline 気 & 熟 & 鋼 管 型 & 鋼 管 型 \\
\hline 开 油 用 & $=-t$ & 蒸気嗢蓩式 & 压力噴蓩式 \\
\hline
\end{tabular}

\section{$2 \cdot 1$ 腐食プロープによる試験 ${ }^{3)}$}

\section{$2 \cdot 1.1$ 腐食プローフ}

この試験片は写真 1 および試験片先端部詳細は図 1 に示す。半球状の試験片 (M) は表面積約 $18 \mathrm{~cm}^{2}$, 厚さ $5 \mathrm{~mm}$ の軟鋼製で, 裏面から熱電対, 鉄一コンスタン タン線 $(0.5 \mathrm{~mm} \phi)$ を埋込んである。これを長さ $1.2 \mathrm{~m}$, 直径 $32 \mathrm{~mm} \phi$ の支持鋼管 $(\mathrm{P})$ の先端に取付けてある。 この試験片は支持鋼管中の導管を通した圧縮空気により 


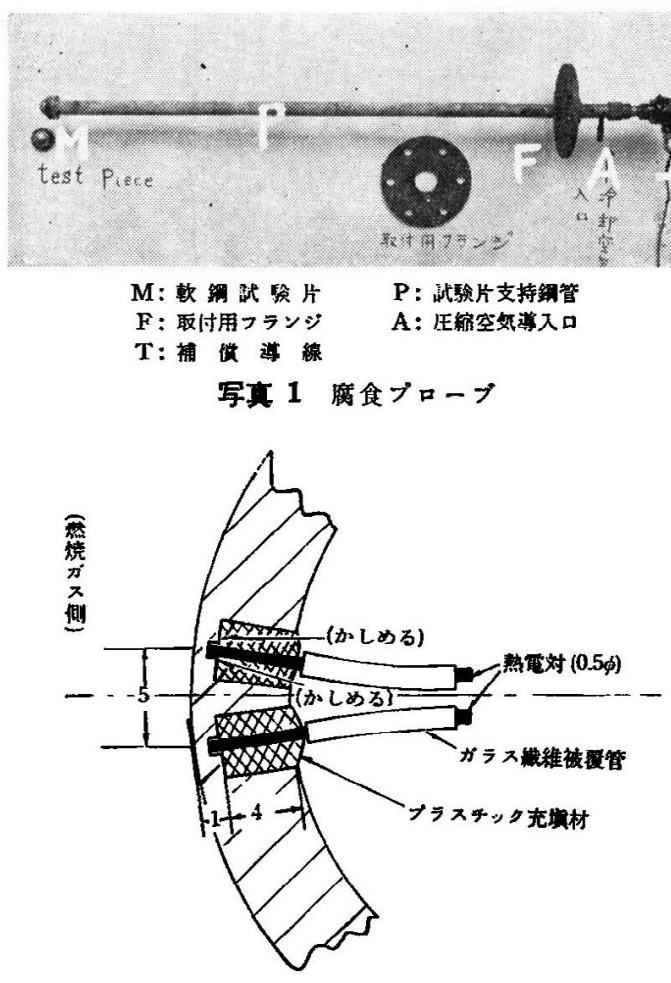

图 1 試験片先端部詳細図

所定の温应に調節できるょうにしてある。なお，試験片 の表面温度は，别に作った同じ型の試験片によりチェッ クした。この調験片は，武藏工大古浜庄一教授の試作に よるもので, 熱電対測温接点は深さをかえて 3 力所に埋 込えである。表面温度はこの 3 点の温度を外㨂して推定 した。

\section{$2 \cdot 1 \cdot 2$ 試験方法}

試験片の表面は，使用以先立って研摩紙(エメリー04) で十分にみがきフルコールを浸した脱脂綿で清める。 プロープは湮道ガスの流れと直角を保つように㖶道内に 捅入する。測定は 2 本のプローブを同㭙に挿入して行な 弓。測定位置は, 表 1 No. 4 B の場合, 空父予熱器中 間部 (ガス温度約 $180^{\circ} \mathrm{C}$ ), No. $11 \mathrm{~B}$ の場合, 空気予熱 器入口部 (ガス温度的 $250^{\circ} \mathrm{C}$ ) である。試駼条件は 95

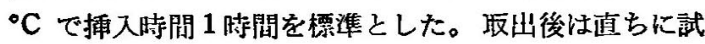
験片に蒸留水を吹付け表面の付着物をピーカーに洗い落 す。洗液はガラスフィルター（G-4）で沪別する。残渣 は必要があれば科量する。沪液は $250 \mathrm{cc}$ とし分析用陚 料とする。

\subsection{3 鉄 $の$ 定 $\mathbf{2}^{4}$}

分析用試料より $5 \mathrm{cc}$ をとり，oーフェナントロリン溶 液により発色させ， $1 \mathrm{~cm}$ のセルを用い分光兆度計によ り吸光度を $510 \mathrm{~m} \mu$ で測定し，検量線により鉄の量を 求め, この鉄量をむって鹰食量とした。

\subsubsection{SO4-}

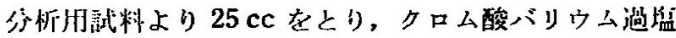
素酸溶液を加える。遊雜した $\mathrm{CrO}_{4}^{2}$ は $1 \mathrm{~cm}$ のセルを

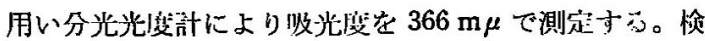
量線により $\mathrm{SO}_{4}^{2-}$ の量を求める。

\section{2 空気予熱器付肁物の分析 ${ }^{6)}$}

\subsection{1 付着物の採取}

銅管型空父子熱器（衣 1 No. 4 B) 付着物の採取化あ たっては、このボイラが陚験斯间だけ西油燃燒を行なっ たむのであるから，不炭焚きの影凘をさけるたり，あら かじめ銅管队は十分清据して打き，試験終了後付涽物を 取出した。他の発電所におけるコングストロ一ム型（再

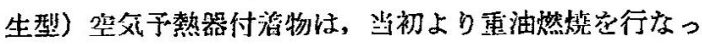
ていたボイラにおけるもので，銅板からかき落して採叹 した。

\section{$\mathbf{2 \cdot 2 \cdot 2}$ 分析方法}

採取した試料は，インクリメント縮分法により，約 5 gとし, 水 $150 \mathrm{cc}$ に溶解沪別する。残渣は $80^{\circ} \mathrm{C}$ で乾 燥, 称量後 $1,000^{\circ} \mathrm{C}$ で灼熱する。残量を灰分さし, そ の間の減量を未燃分 (可燃性残渣) とする。沪液の一部 をとり，H 型イオン交換樹脂で処理後(この際付畕物中 に $\mathrm{Cl}^{-}, \mathrm{NO}_{3}^{-}$憀められなかった)，N/10 NaOH で 滴定し, $\mathrm{SO}_{4}^{2-}$ を求的る。 $\mathrm{Fe}^{2+}$ は, 沪液の一尖をとっ て搌硫酸を少量扣え， $N / 10 \mathrm{KMnO}_{4}$ の滴定により，ま

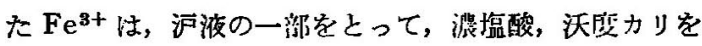
加并， $N / 100 \mathrm{Na}_{2} \mathrm{~S}_{2} \mathrm{O}_{3}$ で滴定して求めた。このほか， ドロマイト注入哳の付着物の場合には，沪液の一部安と り，鉄を除去後，EDTA で滴运して $\mathrm{Ca}^{2+}, \mathrm{Mg}^{2+}$ を 求めた。

\section{3. 結果と考蜞}

\section{1 表面温度の影旿}

空父予熱器出口に拈ける排ガス温度は，ボイラの熱奻 事を高めるために，できるだけ下げることが望交狆てい

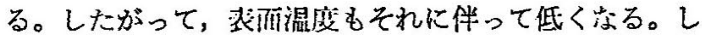
かし，表面温度の低下とともに腐食も次第に塪寸ために 運転上，約 $75^{\circ} \mathrm{C}$ が表面温废の限度とされているようで

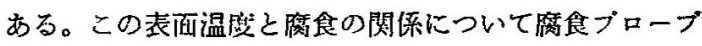
による結果を図 2，および图 3 に示寸。これらの結果 は, ボイラの型式，過剩空父率および燃料油中の硫黄分 などがそれぞれ異なる場会のるのであるが，表而温度と 腐食量の閵係は，いずれ子表治温度の低下にともなって 應食量が增加を示している。図 3 では，70〜90 $\mathrm{C}$ の閩 で腐食量に大差は見られないが，60 增すようである。腐食量と同㭙に定量した $\mathrm{SO}_{4}^{2-}$ るこ れと大体同じ傾向である。

このように鹰食量が表面温度の低下に伴って次第に増 加を示すという傾向は，D. Flint \& R. W. Kear らの 


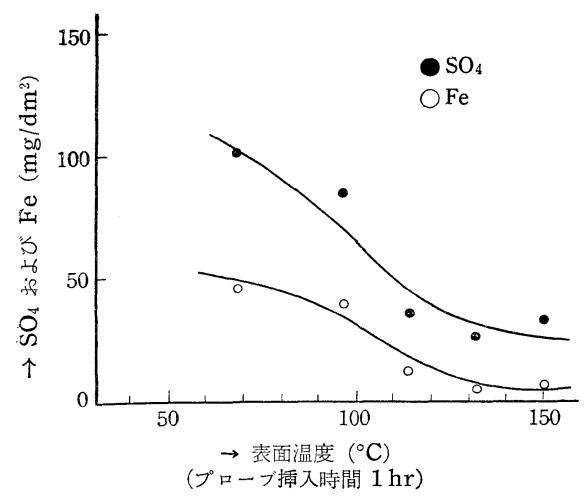

ボイラ: 鶴見発電所 No. 11 B

然料油中の硫黄分: $2.7 \%$

然狫ガス中の $\mathrm{O}_{2} \%: 5.0 \sim 5.5 \%$ (空気予熱器ガス出口にて) 平均值の信頼限界（信頼度 $95 \%$ ): $\mathrm{Fe} \pm 14 \mathrm{mg} / \mathrm{dm}^{2}$

$\mathrm{SO}_{4} \pm 27 \mathrm{mg} / \mathrm{dm}^{2}$

図 2 表面温度と腐食量の関係一 1

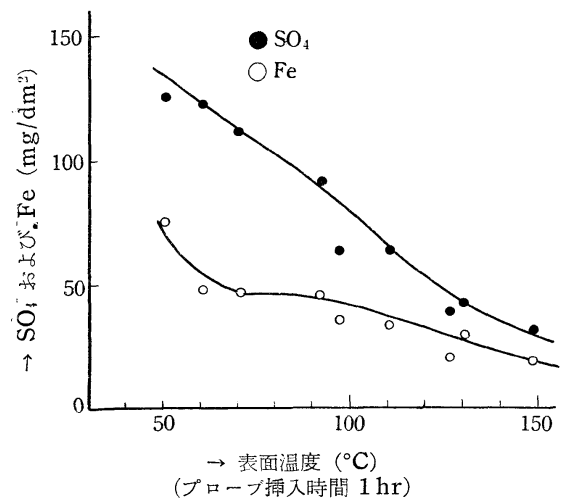

ボイラ: 鶴見発電所 No. 4 B

燃料油中の硫黄分: $2.1 \%$

燃焜ガス中の $\mathrm{O}_{2} \%: 4.5 \sim 4.9 \%$ (空気予熱器中間部にて)

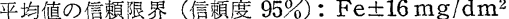
$\mathrm{SO}_{4} \pm 28 \mathrm{mg} / \mathrm{dm}^{2}$

図 3 表面温度と腐食量の関係- 2

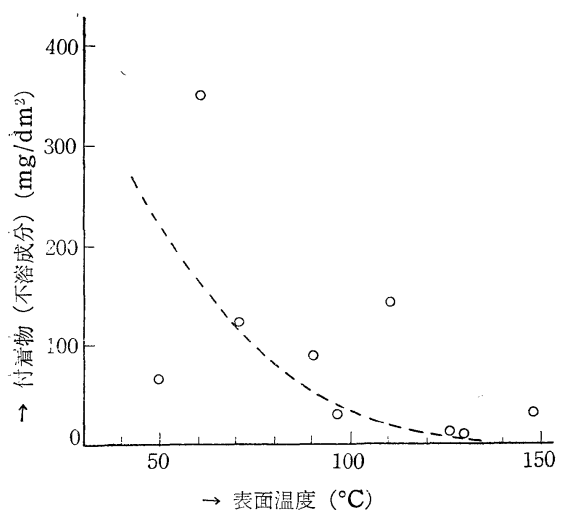

ボイラ: 鶴見発電所 No. 4 B

試 料: 図 3 と同じ

平均值の信頼限界 (信頼度 $95 \%$ ) : $\pm 40 \mathrm{mg} / \mathrm{dm}^{2}$

図 4 表面温度と付着物の関係

実験結果7) と異なっている。彼らの結果では, 露点以下 約 $30^{\circ} \mathrm{C}$ に拈いて腐食量に一つの極大值が示されてい
る。この現象については議論のあるところであるが，こ れは燃焼ガスと表面温度とが， ある温度差以上になる と，ガス中の硫酸がミストとして運汭れてしまい，硫酸 の表面への凝縮量が減少するため, 腐食量に变化を生じ ると説明されている。この腐食量に極大值が認められる という裴面温度域に空父予熱器の表面温度域が入るの で，このような腐食現象が存在することは間題である。 これについてはさらに検討すべき点であるが，D. Flint らの結果と図 2 , 図 3 に示さ机る傾向のちがいは，図 4 に示亦面温度と付着物の堆積量との関係が，その一つ の説明になろう。図 4 の結果は, 図 3 亿得られた試料に より同時に測定されたものであり，バラッキはあるが， 表面温度が約 $100^{\circ} \mathrm{C}$ 以下では, 付着物の堆積が増加を

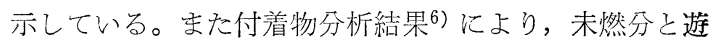
離硫酸とは正の相関関係があると推定されているから， ガス中に運び去られるはずの硫酸分が，この付着物とと もに表面に凝縮したため, 腐食量の極大值が存在しなか ったものと考えられる。なおガス中の水分含有率が一定 の場合, 表面に凝縮した硫酸の平衡濃度注, 図 $\mathbf{5}$ に示さ れるように，そこの表面温度で定まると推定されてい る8)。したがってこのような環境下における表面の腐食 については硫酸濃度, あるい硫酸の凝縮速度などとの 関係よりさらに究明されるべき問題と考えられる。

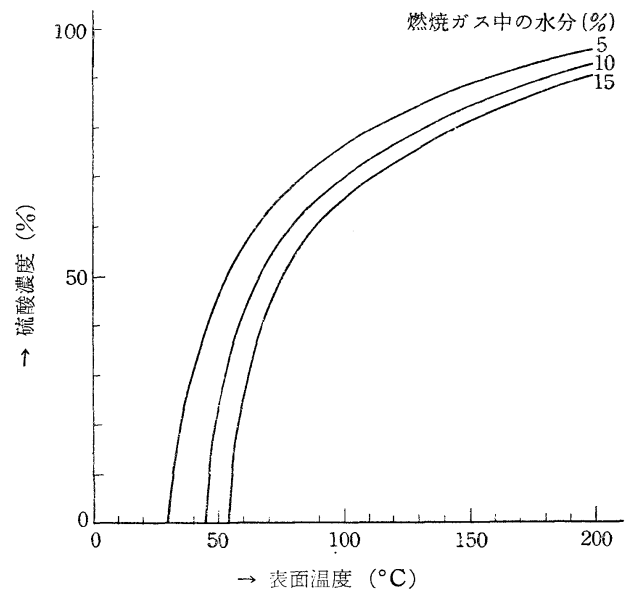

図 5 表面温度と凝縮した硫酸の平衡濃度

\section{$3 \cdot 2$ 燃料中の硫黄分の影響}

然料中の硫黄分と腐食量, および燃燒ガス中の $\mathrm{SO}_{3}$ 含有率との関係汇図 6 に示す。この結果注, 同一ボイラ において同じ試験期間中に行なわれたものである。いず れも硫黄分の増加に伴い, parabolic な傾向で増加を示 している。この関係を図7に示すと腐食量は, 燃焼ガス 中の $\mathrm{SO}_{3}$ 含有率の増加により, 指数関数的に増加を示 す。この曲線と $x$ 軸との交点は, 燃燒がス中に $\mathrm{SO}_{3}$ が 存在していても腐食が見られない場合である。このよう 


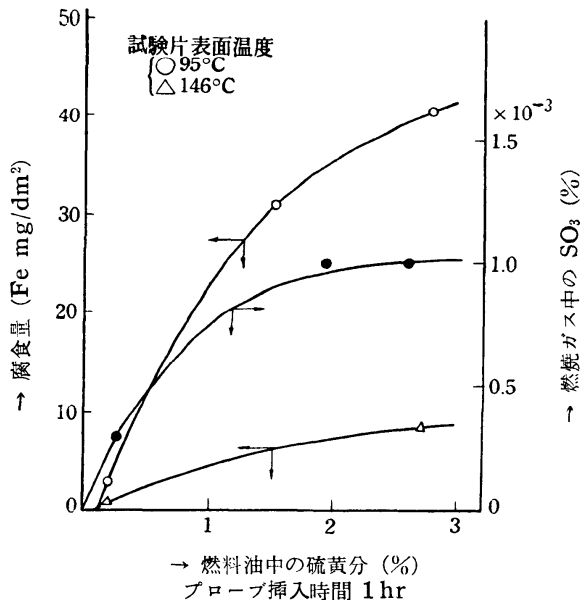

ボイラ: 鶴見発電所 No. $11 \mathrm{~B}$

燃娔ガ ス中の $\mathrm{O}_{2} \%: 5.0 \sim 5.5 \%$ (空気予熱器ガ ス出口にて) 平均値の信頼限界（信頼度 $95 \%$ )：腐食星 $\pm 14 \mathrm{mg} / \mathrm{dm}^{2}$

図 6 燃料油中の硫黄分と腐食量および然焼 ガス中の $\mathrm{SO}_{3}(\%)$ の関係

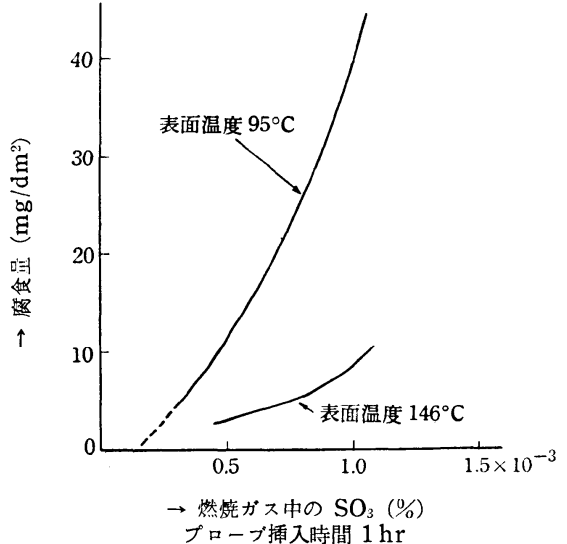

図 7 腐食量に及ぼす燃焼ガス中の $\mathrm{SO}_{3}(\%)$ の影響

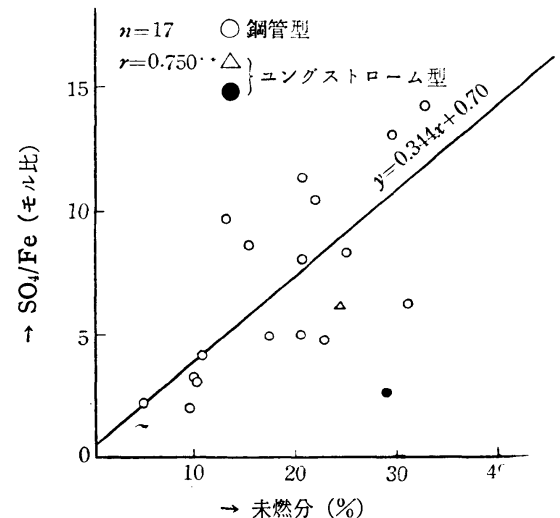

$n$ : 試料数 $\quad r$ : 相関係数 (***高度に有意であることを示す)

図 8 付着物中の $\mathrm{SO}_{4} / \mathrm{Fe}$ (モル比) と末燃分の関係 な $\mathrm{SO}_{3}$ 濃度のガスでは, その露点が試験片表面温度の $95^{\circ} \mathrm{C}$ より低いことを示すものと推定される。

$3 \cdot 3$ 空気予熱器付着物中の未燃分と遊離硫酸について

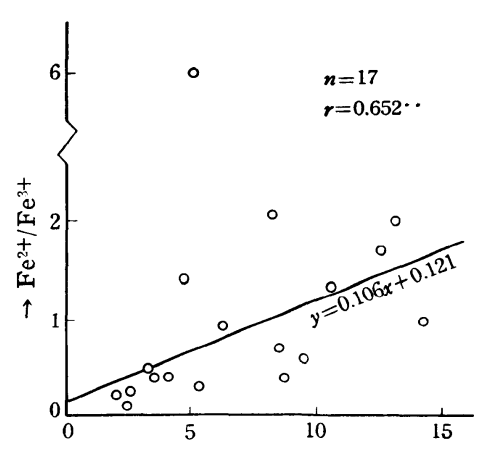

$\rightarrow \mathrm{SO}_{4} / \mathrm{Fe}$ (モル比)

銅管型空父禾 熱器および一， 二のエングスト ロ 一厶型空父予 熱器より採取し た付着物の分析 維果を図 8 打よ び図 9 に示す。 図 8 では付曾 物中の $\mathrm{SO}_{4} / \mathrm{Fe}$ （モル比）と末燃

図 9 付着物中の $\mathrm{SO}_{4} / \mathrm{Fe}$ (モル比) と $\mathrm{Fe}^{2+} / \mathrm{Fe}^{3+}$ の関係

分の閌には正の 相関々係のある ことが示される。硫酸鉄が腐食生成物の多くを占めるか ら，このモル比が 1〜1.5 以上は遊離硫酸の存在を示一 ものである。すなわち遊離硫酸の堆程は未燃分と密接な 関係にあるといえる。

\section{4 付着物中の腐食生成物之硫酸分について}

図 9 は遊離硫酸と $\mathrm{Fe}^{2+} / \mathrm{Fe}^{3+}$ との関係を示したもの である。付着物中に打ける遊離硫酸の増加により，腐食 生成物中における硫酸第一鉄が第二鉄塩より次第に多く なることが推定できるが，これについては次のように考 えられる。遊離硫酸が増すに伴って腐食反応が激しく進 み，腐食生成物が多量に生成するため酸素が欠さ状態と

表 2 付着物の $\mathrm{X}$ 線分析結果

\begin{tabular}{|c|c|c|}
\hline & 鋼管型空気予熱器* & ユングストローム型空気予熱器 \\
\hline $\mathrm{X}$ 線回折 & $\begin{array}{l}\mathrm{FeSO}_{4} \cdot 4 \mathrm{H}_{2} \mathrm{O} \\
\mathrm{Fe}_{2}\left(\mathrm{SO}_{4}\right)_{3} \cdot \mathrm{H}_{2} \mathrm{SO}_{4} \cdot 8 \mathrm{H}_{2} \mathrm{O} \\
\left.\mathrm{FeSO}_{4} \cdot \mathrm{H}_{2} \mathrm{O} \text { (ッララシ }{ }^{2}\right)\end{array}$ & $\begin{array}{l}\mathrm{FeSO}_{4} \cdot 4 \mathrm{H}_{2} \mathrm{O} \\
\mathrm{FeSO}_{4} \cdot 7 \mathrm{H}_{2} \mathrm{O}\end{array}$ \\
\hline \multirow{2}{*}{ 螢光 X線 } & \multirow{2}{*}{$\underline{\underline{\mathrm{Fe}}} \underline{\mathrm{Ni}} \mathrm{Zn} \mathrm{Cu} \mathrm{V}$} & $\mathrm{Cu} \mathrm{Zn} \mathrm{Ni} F \mathrm{Mn}$ \\
\hline & & $\mathrm{Pb} \mathrm{Zn} \mathrm{NiCu} \mathrm{Fe} \mathrm{V}$ \\
\hline
\end{tabular}

鶴見発電所 No. 4 B

一比較的多いと思执るもの，＝いくぶん多いと思われるもの

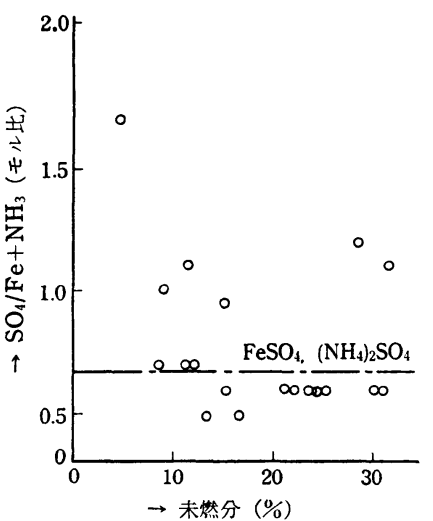

図 10 付着物中の $\mathrm{SO}_{4} / \mathrm{Fe}+\mathrm{NH}_{3}$ （モル比）と末然分 (フンモニフ吹込の場合)
なり，零囲父が鮞元

性となる。したがっ て $\mathrm{Fe}^{2+}$ の酸化が抑 制され，このような 環境下において生成 した腐食生成物で は, $\mathrm{Fe}^{2+}$ の方が $\mathrm{Fe}^{3+}$ より多く存在 することになるもの といえよう。このこ とは, X線回折結果 （表 2）において硫酸 第一鉄の存在が確認 されたことからも説 


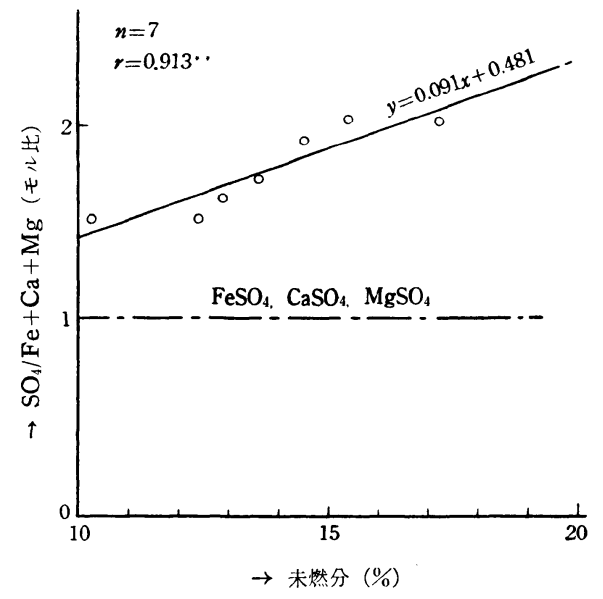

図 11 付着物中の $\mathrm{SO}_{4} / \mathrm{Fe}+\mathrm{Ca}+\mathrm{Mg}$ (モル比) と 末然分の関係（ドロマイト吹込の場合）

明できる。図 10 および図 11 は煙道ガス中にアンモニ ア，ドロマイトなどをそれぞれ吹込んだ場会の付看物の 分析結果を示したものである。いずれも中和により遊離 硫酸がほとんど含まれていないか，あるいは存在しても わずかになっている。これらの付着物中の $\mathrm{Fe}^{2+} / \mathrm{Fe}^{3+}$ は, 0.6〜0.7 であり, 図 9 と比べて $\mathrm{Fe}^{3+}$ の方が $\mathrm{Fe}^{2+}$ より多い傾向を示している。またX線分析によっても第 一鉄塩は確涊されていない。このこと法空父予熱器の腐 食生成物が零囲気により異なることを示すものといえよ う。さて硫酸第一鉄の融点 $\left(64^{\circ} \mathrm{C}\right)$ 注，推定される空父 予熱器衣面温度より低いので, 表面においては溶融状態 となり, 流下堆積し未燃分, 灰分などの溶着を促進さ せる原冈になると推定される。また腐食生成物として $\mathrm{FeSO}_{4} \cdot 4 \mathrm{H}_{2} \mathrm{O}$ などが確垫されているので, これらの除 去には，その水に対する溶解度が最大を示卞約 $65^{\circ} \mathrm{C}$ の 熱水による洗浄が効果的といえよう。

\section{4 未燃分中の炭化水素について}

未然分の元素分析の結果 (表 3)，水素が涩められたの で炭化水素の存在を推定し，赤外線分光分析を行なった 結果，炭化水素が確忍され，またそれらは二重絬合を有 するものであることも梁められた。このような炭化水素 の存在は,その堆積の原因を一層複雑に寸るものである。 特に微量ではあるが，二重結合を有する炭化水素と遊離 硫酸の共存状態より，炭化水素の重合生成物とか，ガム 質9)の存在も予想されるが，その確認は今後に残された

表 3 空気予熱器付着物の元素分析結果

\begin{tabular}{|c|c|c|c|c|c|c|}
\hline \multicolumn{3}{|c|}{ 空気予熱器 } & \multicolumn{3}{|c|}{ エングストローム型 } & 鋼管 刑* \\
\hline $\begin{array}{l}\text { 水 } \\
\text { 全 } \\
\text { 硫 } \\
\text { 水 } \\
\text { 窒 }\end{array}$ & $\begin{array}{l}\text { 分 } \\
\text { 黄 } \\
\text { 素 } \\
\text { 萦 } \\
\text { 素 }\end{array}$ & $\begin{array}{l}\% \\
\% \\
\% \\
\% \\
\%\end{array}$ & $\begin{array}{r}7.19 \\
13.21 \\
36.21 \\
1.65 \\
0.18\end{array}$ & $\begin{array}{r}23.27 \\
12.92 \\
28.40 \\
1.54 \\
0.22\end{array}$ & $\begin{array}{r}1.7 \\
3.6 \\
83.5 \\
0.1 \\
0.8\end{array}$ & $\begin{array}{r}2.0 \\
3.8 \\
67.8 \\
0.1 \\
0.6\end{array}$ \\
\hline
\end{tabular}

* 鶴見発電所 No. 4 B
問題である。

\section{4. 結}

言

重油燃焼ボイラの空父予熱器の腐食が注目されていな がら，そこに堆積与る付筸物についてはあまり検歊され ていなかった。筆者らは，この部分に打ける腐食現象を 検討与るにあたり，扮もにそこに堆程した付着物に注目 し，またその分析絬果より考察を行なった。打もな結果 は次のように要約される。

1）腐食プローブによる絬果では，衣西温度が低下す るに伴って腐食量, 付着する硫酸量および付活物などの 堆皘が增す傾向が㴓められた。しかし腐食量に一つの極 大梿を示与ような温度域は涊められなかった。

2) 空父予熱器付着物中に含まれる遊離硫酸と未燃分 および $\mathrm{Fe}^{2+} / \mathrm{Fe}^{3+}$ との間には，正の相関々係が热めら れ，また付着物中の腐食尘成物としては硫酸第一鉄が確 認された。

これらのことは，付篔物中に存在する未燃分と遊離硫 酸が正の相関々倸にあり，また韭面の零囲父は付着物の 堆積により還元性が保たれていること，および裔面温度 の低下にしたがって付筧量が增加する傾向のあることな ぞによるといえよう。

3）燃焼ガス中への硫酸中和剤の吹込みにより，付着 物および腐食生成物の組成に变化が涩められたが，この ことは付着物の堆栍に硫酸が影響していることを裏付け るとともに，添加鼡倾用が效果的であったことを示した ものといえる。

な抢ガス中の硫酸の衣面への凝縮速度および峳面に凝 縮した硫酸湠度の決定などは残された問題点であるう。

終りに，種々ご教示を頂いた東京工業試験所第 6 部第 4 課長重野隼太氏，現場試験において御協力頂いた東京 電力 K K 鶴見発電所関係各位ならびに同所田中侹二氏， 試験片温度測定にご協水頂いた武蔵工大古浜庄一教授, また終始实験に協水された当所化学研究室矢田部照夫， 杉野邦雄氏の各位に刘し深甚の謝意を表する次第であ る。

（昭和 35 年 12 月 26 日受理）

\section{文献}

1）たとえば L.K. Rendle, R.D. Wilsdon \& G. Whittingham: 5th. World Petr. Congress Sect. VII, Paper 11 (1959)

2）たとえば P.D. Moskovits：Ind. Eng. Chem., 51，1305 (1959)

3) G. G. Thurlow: J. Inst. Fuel., 25, 252 (1952)

4) APHA et al.: "Standard Method for the Examination of Water, Sewage, and Industrial Wastes" p. 125 (1955)

5) 加藤外：日化, 76, 373 (1955)

6）大塚，下田外：電力中解技研報告（化学 60002）（1960)

7) D. Flint \& R.W. Kear: J. Appl. Chem., 1, 388 (1951)

8) H. D. Taylor: Trans. Faraday Soc., 47, 1114 (1951)

9）たとえば 風当：化学と工業，10，No. 1，21（1957） 